\title{
Biotracers and geotracers of depositional events in NW Mediterranean margin over the past two centuries
}

\author{
Pierre GIRESSE $^{a *}$, Roselyne BUSCAIL ${ }^{\mathrm{b}}$, Bruno CHARRIÈRE $^{\mathrm{b}}$, Abderrazzak ABASSI $^{\mathrm{b}}$ Pere MASQUÉ $^{\mathrm{c}}$, \\ Joan-Albert SANCHEZ-CABEZA ${ }^{\mathrm{c}}$ \\ ${ }^{a}$ Laboratoire de sédimentologie marine, université de Perpignan, avenue de Villeneuve, 66860 Perpignan, France \\ ${ }^{\mathrm{b}}$ Centre de formation et de recherches sur l'environnement marin, université de Perpignan, avenue de \\ Villeneuve, 66860 Perpignan, France \\ ${ }^{\mathrm{c}}$ Centre d'Estudis Amvientals, Departament de Fisica, Universitat Autònoma de Barcelona, 08193 Bellaterra, \\ Barcelona, Spain
}

Received 8 June 2001; revised and accepted 9 October 2001

\begin{abstract}
A detailed sedimentological and geochemical investigation was performed on slope sediments collected from the Gulf of Lions and Catalonian margins and from the northern Balearic margin. The study was based on cores, about $50 \mathrm{~cm}$ long. Various physiographic sites (canyons, open slopes) were selected according to the available sediment accumulation rates obtained with the ${ }^{210} \mathrm{~Pb}$ geochronological method. At a short time scale, various parts of the slope were characterized by muddy hemipelagic sediment. Sedimentological data suggested that deposition was continuous. Total organic carbon and its hydrolysable fraction decreased downcore. Significant increase of C/N ratio downcore resulted from an early diagenetic process in response to the burial effect. However in other parts, the values of the $\mathrm{C} / \mathrm{N}$ ratio were found to be irregular and maxima could frequently be related to both higher sand content and relict coastal remains derived from erosion and reworking of outcropping deposits of the last glacial maximum (lowstand system tract). Such tracts crop out over much of the shelf slope break seafloor. They provide various biological and lithological indicators: relatively well-preserved Miliolidea, coastal or lagoonal foraminifera (Ammonia beccarii, Elphidium crispum), Characea oogons, oxidized beach-rock debris, gypsum, previously mature glauconite (with cracks) and coarse vegetal debris. Throughout the sections, the degree of diagenetic overprinting of the organic matter frequently showed a positive correlation with the abundance of some coastal indicators supporting the hypothesis of sedimentation induced predominantly by gravity These downslope accumulation may correspond to $10-40 \%$ of the total deposit. The gravity induced transfers have been shown to be negligible in the sediment record of the northern Balearic margin. It is suggested that a reduced sedimentation rate (half that observed in the Gulf of Lions) would be expressed by a higher stability of the slope. The consequence of low sedimentation would be early diagenetic solution/reprecipitation of carbonate near the redox transition layer. (c) 2001 Ifremer/CNRS/IRD/Éditions scientifiques et médicales Elsevier SAS
\end{abstract}

Résumé - Bio- et géotraceurs des processus sédimentaires de la marge nord-ouest de la Méditerranée à l'échelle des deux derniers siècles. Une étude sédimentologique et géochimique détaillée des dépôts de pente du golfe du Lion, de la Catalogne et du Nord des Baléares à partir de carottes courtes ne dépassant pas $50 \mathrm{~cm}$ a été effectuée. Les sites

* Correspondence and reprints.

E-mail address: giresse@univ-perp.fr (P. Giresse).

(C) 2001 Ifremer/CNRS/IRD/Éditions scientifiques et médicales Elsevier SAS. Tous droits réservés 
présentés (canyons, interfluves) ont été choisis en fonction de l'existence de taux de sédimentation mesurés à l'aide de la méthode au ${ }^{210} \mathrm{~Pb}$. À cette échelle de temps réduite, plusieurs régions de la pente sont caractérisées par une accumulation de vases hémipélagiques. Les observations sédimentologiques suggèrent un processus continu de la sédimentation. Le carbone organique total ainsi que sa fraction hydrolysable tendent à diminuer du haut vers le bas de la carotte ; à l'inverse une nette augmentation du rapport $\mathrm{C} / \mathrm{N}$ est observée. Cette augmentation traduit les effets d'une diagenèse précoce conséquente de l'enfouissement. Cependant, dans certains sites, le profil vertical du C/N est irrégulier et les maxima peuvent être souvent corrélés à la fois avec des teneurs en sable plus élevées et avec l'abondance de débris issus de l'érosion et du remaniement des dépôts littoraux du dernier bas niveau glaciaire. Ces derniers qui tendent à affleurer à proximité de la rupture de pente entre le plateau et la pente sont reconnus grâce à plusieurs marqueurs littoraux : Miliolidea assez bien préservés, foraminifères côtiers ou lagunaires (Ammonia beccarrii, Elphidium crispum), oogones de Characées, fragments oxydés de grès de plage, gypse, glauconie évoluée et débris grossiers de végétaux. La fréquente association de ces indicateurs côtiers avec le degré avancé de l'évolution diagénétique correspond à des épisodes où l'accumulation gravitaire joue un rôle important pouvant représenter de 10 à $40 \%$ du sédiment total. Sur la marge septentrionale des Baléares, ces processus gravitaires paraissent avoir joué un rôle négligeable. Il est suggéré que la vitesse de sédimentation réduite correspond à une plus grande stabilité de la pente. En conséquence de cette lenteur de la sédimentation, les carbonates sont l'objet d'une diagenèse précoce avec des processus de dissolution et de reprécipitation à proximité de la limite d'oxydoréduction. (c) 2001 Ifremer/CNRS/IRD/Éditions scientifiques et médicales Elsevier SAS

\section{north-western Mediterranean / sedimentation rate / gravity-induced process / organic carbon / ${ }^{210} \mathrm{~Pb}$}

\section{Méditerranée nord-occidentale / vitesse de sédimentation / processus gravitaires / carbone organique / ${ }^{210} \mathrm{~Pb}$}

\section{INTRODUCTION}

Continuing research over the Gulf of Lions continental margin deposition has been carried out for some decades Courp and Monaco, 1990; Got and Aloisi, 1990). These studies placed a strong emphasis on Holocene accumulations and their relationship to physical and biological structures, grain size, organic geochemistry and proportion of the major sediment components. However, relatively few slope sites have been investigated to the scale of the last hundred years, the Lacaze-Duthiers canyon being a noticeable exception Courp and Monaco. 1990) Until recently, few records concerning the Catalonian slope and the northern Balearic margin were available for comparison of the sedimentary processes (Palanques and Puig. 1999: Sanchez-Cabeza et al. 1999.

Well-documented cores in various physiographic sites (axial channel of canyons, open slopes) were selected between 500 and $2000 \mathrm{~m}$ of water depth in the northwestern Mediterranean margin (Gulf of Lions and Catalonian slopes) and in the northern Balearic margin.

In this paper, we observed bed-by-bed the uppermost $50-\mathrm{cm}$ layers of undisturbed sample sediment. The primary objectives of the investigation are i) to propose a typology of the main governing factors such as sediment accumulation rates, mineralogical and organic processes of sedimentation; ii) to characterize a variety of sedimentary facies and geochemical markers that are genetically related to sediment gravity flows; iii) on this basis, to assess the relative amplitude of these gravity-induced process and to suggest, if possible, a quantitative approach that can be integrated into a budget for the last hundred years. Here, a comparison is made between the different portions of the studied margin and thus permit to pinpoint the diagenetic processes affecting carbonate particles of the Balearic margin. Furthermore, this approach permitted us to examine some discrepancy between apparent radiocarbon ages and ${ }^{210} \mathrm{~Pb}$ chronology.

\section{MATERIALS AND METHODS}

Some thirty sediment cores of the upper deposits (30-45 cm long) were collected by multitube corers on the north-western Mediterranean margin and on the northern Balearic margin during Flubal 1993, Concentra 1993, Euroswap 1994 and Euromarge 1995 cruises. Twelve representative stations between 500 and around $2000 \mathrm{~m}$ of water depth (figure -1 ) were selected accord 


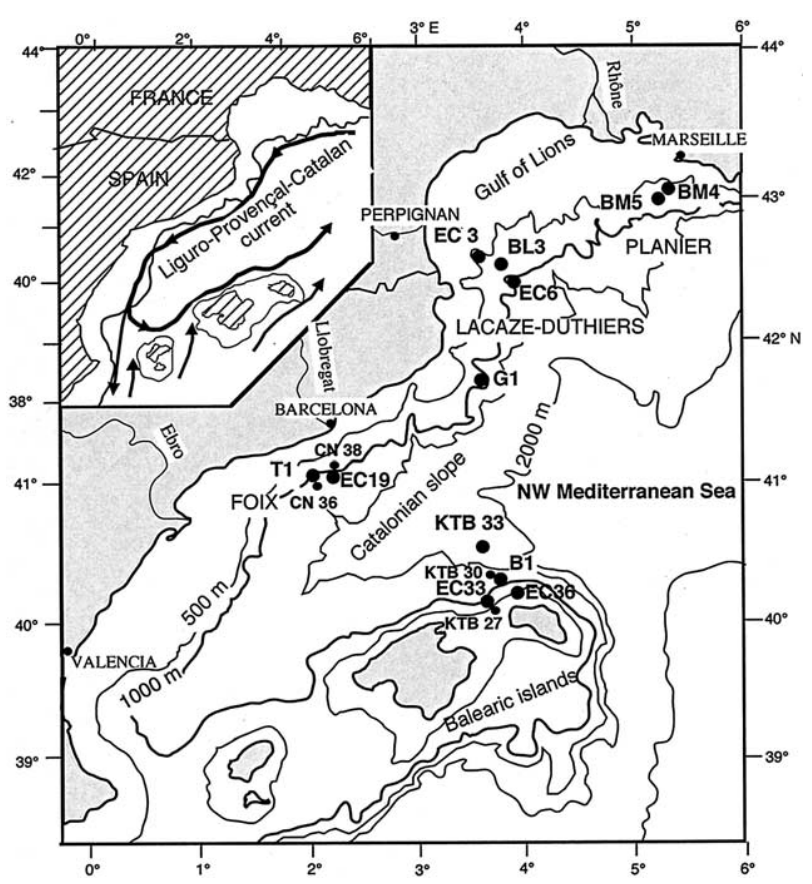

Figure 1. Location map of sediment cores sampled on the northwestern Mediterranean margin (Gulf of Lions, Catalonian and north Balearic slopes). The general circulation (Liguro-Provençal-Catalan Current) is shown in inset.

ing to the available sediment accumulation rates obtained with the ${ }^{210} \mathrm{~Pb}$ geochronological method.

Sediment accumulation rates were determined in several cores by means of the ${ }^{210} \mathrm{~Pb}$ geochronology (Abassi. 1998: Masqué, 1999) by using a modified version of the CRS method CAppleby and Oldfield, 1978; Sanchez Cabeza et al. 1998) ${ }^{210} \mathrm{~Pb}$ analyses on some of the sediment samples were performed following the methodology described by Sanchez-Cabeza et al. (1998), by total digestion of $200-300 \mathrm{mg}$ sample aliquots, ${ }^{209} \mathrm{Po}$ was added in each sample before digestion as internal tracer. After digestion, samples were made with $1 \mathrm{~N} \mathrm{HCl}$ and ${ }^{209} \mathrm{Po}$ and ${ }^{210} \mathrm{Po}$ were deposited onto silver disks at $60-70{ }^{\circ} \mathrm{C}$ for $8 \mathrm{~h}$ while stirring. Polonium isotopes were counted with $\alpha$-spectrometers equipped with low background SSB detector (EG\&G Ortec). Due to the elapsed time span between sediment sampling and analyses, ${ }^{210} \mathrm{~Pb}$ was assumed to be in radioactive equilibrium with ${ }^{210} \mathrm{Po}$ (half-life $=138 \mathrm{~d}$ ) in the sediment samples.

Cores were sampled at $1 \mathrm{~cm}$ depth intervals in the uppermost 10 and at 2 or $5 \mathrm{~cm}$ intervals in the lowest part. Organic compounds were analysed in ground subsamples previously freeze-dried and weighted. After wet-sieving $(50 \mu \mathrm{m})$, the sandy fraction was examined with a stereomicroscope. Images were also obtained using a scanning electron microscope (SEM) coupled with an Energy Dispersive Tracor microprobe for studying the shape and composition of the selected particles. Total carbon and organic carbon (OC) contents of the whole sediment were measured using a Leco induction furnace after acidification with $2 \mathrm{~N} \mathrm{HCl}$ for OC. Calcium carbonate content was calculated from inorganic carbon using the molecular mass ratio 100/12 (i.e. $\mathrm{CaCO}_{3} / \mathrm{C}$ ). Hydrolysable organic carbon (HOC) is given by the fraction of total organic carbon hydrolysed by $6 \mathrm{~N} \mathrm{HCl}$ for $16 \mathrm{~h}$ at $110^{\circ} \mathrm{C}$. Total nitrogen was obtained after mineralization $\left(\mathrm{H}_{2} \mathrm{SO}_{4}+\right.$ catalyser at $400{ }^{\circ} \mathrm{C}$ ) and measured by the Kjeldahl method performed with a Büchi automatic analyzer.

In various cores from the north-western area, an irregular proportion of gravity induced input was recognized through the concentration of various tracers of low-stand deposits originating from the shelf break: altered or preserved tests of Quinqueloculina seminulum, Elphidium crispum, Ammonia beccarii, brown or black Characea oogons, oxidized debris, glauconitic molds or grains, rusty worm tubes and gypsum crystals (Goure 2). It was proceeded to a counting of the amount of these particles, $n$ is plotted to a $10-\mathrm{g}$ sand basis.

\section{RESULTS}

\subsection{Depositional setting and spatial variation}

The water mass circulation of this area is largely controlled by the associated current, called the LiguroProvençal-Catalan or Northern Current that flow towards the SW and along the continental slope as part of the whole cyclonic circulation of the north-western Mediterranean sea Millot, 1990, for the Gulf of Lions and Font et al., 1988, for the Catalan sea) (Ggure - d). The principal morphological features of the continental slope are submarine canyons and associated gullies, most of them incising the continental slope down to $2000 \mathrm{~m}$. In several sites (Planier canyon off Marseille, Lacaze-Duthiers canyon off Banyuls, and Foix canyon off Barcelona), one of the aims of the study was to elucidate lateral variations in lithofacies assemblages from the canyon axis to the close open slope. Some governing factors such as sediment 


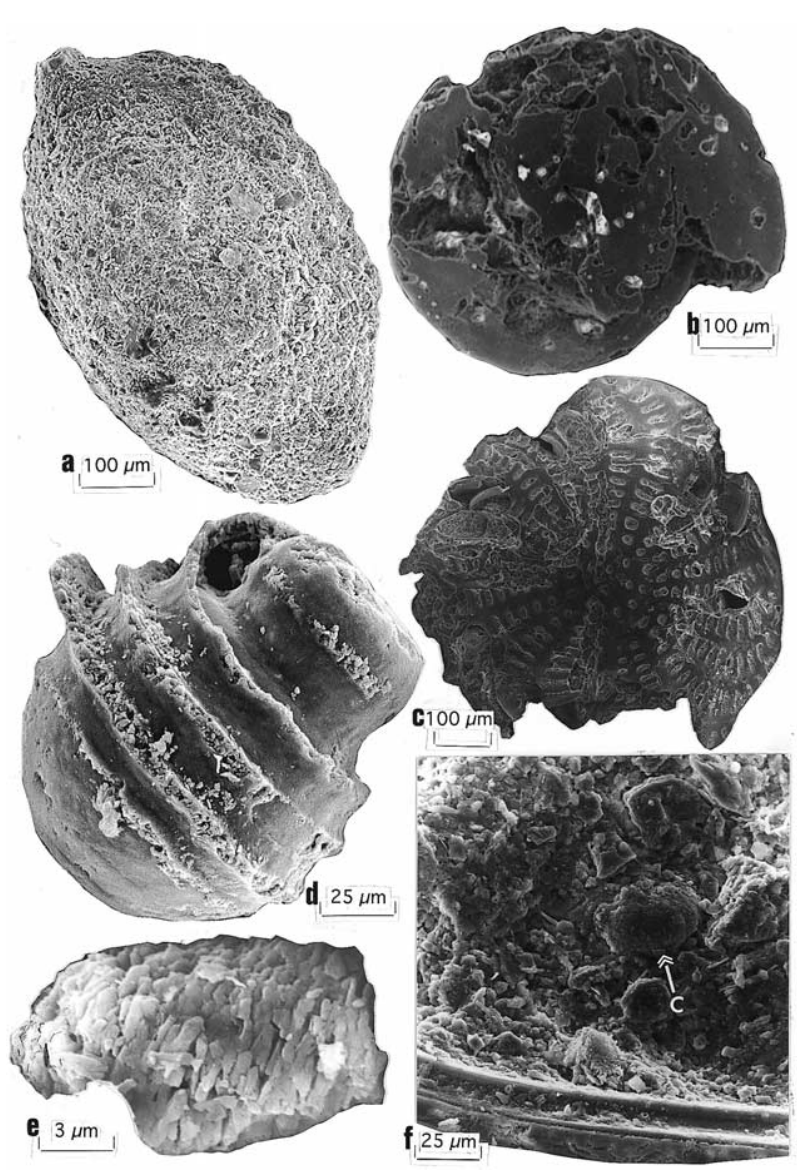

Figure 2. SEM images of various tracers of nearshore deposits of the last low stand: (a) chalky surface of Miliolidae from core BM5; (b) cavernous Ammonia beccarii from core G1; (c) caries inside Elphidium crispum from core BM5; (d) Characea gyrogonite from core BM5. Diagenetic carbonate processes from core B1: (e) aragonitic prisms released from a mollusc bioclast; (f) Globorotalia wall overgrown by calcitic aggregates.

accumulation rates and organic processes of sedimentation have partly been described in other papers Buscai and Germain, 1997; Abassi, 1998: Sanchez-Cabeza et al. 1999: Marin and Giresse, 2001) and will be only summarized in this contribution.

\subsubsection{Sediment accumulation rates}

Since channelling was observed between the shelf break and the $1000-\mathrm{m}$ water depth, mid-slope depocentres can be assumed to occur in the Gulf of Lions and Catalonian margins Buscail and Germain. 1997: Buscail et al. 1997. Sanchez-Cabeza et al. 1999) and the north-western
Atlantic margin Anderson et al._1994. However, ${ }^{210} \mathrm{~Pb}$ accumulation rates evidenced that the highest rates were not systematically found in the canyon axis (table- $)$.

In the Lacaze-Duthiers canyon, accumulation rates ranged from $0.112 \pm 0.010 \mathrm{~cm} \cdot \mathrm{yr}^{-1}$ in the axis to $0.182 \pm 0.009 \mathrm{~cm} \cdot \mathrm{yr}^{-1}$ on the adjacent open slope. In the Planier canyon, rates increased from the axis $\left(0.099 \pm 0.009 \mathrm{~cm} \cdot \mathrm{yr}^{-1}\right)$ to the open slope $(0.144 \pm$ $\left.0.007 \mathrm{~cm} \cdot \mathrm{yr}^{-1}\right)$. For the north-western Mediterranean margin (table 1 ), the sediment accumulation rates on the Gulf of Lions open slope (0.144 \pm 0.007-0.182 \pm $0.009 \mathrm{~cm} \cdot \mathrm{yr}^{-1}$ ) are similar to the rate obtained on the Foix open slope of the Catalonian margin $(0.113 \pm$ $0.005 \mathrm{~cm} \cdot \mathrm{yr}^{-1}$ ), although this increases markedly in the Foix canyon axis $\left(0.580 \pm 0.030 \mathrm{~cm} \cdot \mathrm{yr}^{-1}\right)$. The isolated northern Balearic margin is characterized by general low sedimentation rates $\left(0.085 \pm 0.004 \mathrm{~cm} \cdot \mathrm{yr}^{-1}\right.$ on the open slope and $0.082 \pm 0.030 \mathrm{~cm} \cdot \mathrm{yr}^{-1}$ in the canyon axis) which are independent of the water depth (600 and $1220 \mathrm{~m}$, respectively). These values are the lowest observed in the study area fitting in with low values of suspended matter concentration recorded in the Balearic sea (Pierce and Stanley, 1975). In the deep-water basin (north-east of Mallorca), the sedimentation rates are very low: $<0.05 \mathrm{~cm} \cdot \mathrm{yr}^{-1}$ below $1000 \mathrm{~m}$ and $\sim 0.001 \mathrm{~cm} \cdot \mathrm{yr}^{-1}$ below $2500 \mathrm{~m}$ water depth (7woet_al, 1997)

In relation to sedimentation accumulation rates, two physicochemical parameters were used to distinguish two spatial variations: i) water contents calculated on the basis of dry weight sediment which range from 150 to $190 \%$ on the Gulf of Lions slope, from 100 to $140 \%$ on the Catalonian slope and was approximately $100 \%$ on the northern Balearic slope; ii) the thickness of the oxidized mud layer increases with water depth Buscail et al. 1997) but this differs with the slope bathymorphology - for example, the surface oxidized layers were found to be $9 \mathrm{~cm}$ thick in the axis of the Planier canyon $(1250 \mathrm{~m})$ and $10 \mathrm{~cm}$ thick on the adjacent open slope $(578 \mathrm{~m})$. On the Pyrenean and Catalonian slopes, the reducing conditions appeared at a depth comprised between 7 and $13 \mathrm{~cm}$ in the open slope deposits (BL3, G1, EC19). A small 5-cm thick oxidized layer characterizes the axis of the Foix canyon $(671 \mathrm{~m})$. The Balearic slope displays again features different from the other slope: the oxic-anoxic boundary was observed at the average depth of $20 \mathrm{~cm}$. 
Table I. Depths, positions, linear and mass accumulation rates of the sediment cores taken on the north-western Mediterranean margin (Gulf of Lions, Catalonian and north Balearic slopes). * Data from Abassi, 1998; ** data from Masqué, 1999.

\begin{tabular}{|c|c|c|c|c|c|c|c|}
\hline Station & Location & Cruise & $\begin{array}{l}\text { Depth } \\
\text { (m) }\end{array}$ & Longitude & Latitude & $\begin{array}{l}\text { Linear } \\
\text { accumulation } \\
\text { rate }\left(\mathrm{cm} \cdot \mathrm{yr}^{-1}\right)\end{array}$ & $\begin{array}{l}\text { Mass } \\
\text { accumulation } \\
\text { rate }\left(\mathrm{g} \cdot \mathrm{cm}^{-2} \cdot \mathrm{yr}^{-1}\right)\end{array}$ \\
\hline BM 5 & Planier canyon & FLUBAL 93 & 1250 & $43^{\circ} 00^{\prime} .54 \mathrm{~N}$ & $05^{\circ} 12^{\prime} .58 \mathrm{E}$ & $0.099 \pm 0.009^{*}$ & $0.072 \pm 0.006^{*}$ \\
\hline BM 4 & Planier open slope & FLUBAL 93 & 578 & $43^{\circ} 03^{\prime} .21 \mathrm{~N}$ & $05^{\circ} 18^{\prime} .10 \mathrm{E}$ & $0.144 \pm 0.007 *$ & $0.083 \pm 0.004 *$ \\
\hline EC 6 & Lacaze-Duthiers canyon & EUROSWAP 94 & 1024 & $42^{\circ} 25^{\prime} .57 \mathrm{~N}$ & $03^{\circ} 33^{\prime} .18 \mathrm{E}$ & $0.112 \pm 0.010^{*}$ & $0.108 \pm 0.010^{*}$ \\
\hline EC 3 & Lacaze-Duthiers canyon & EUROSWAP 94 & 596 & $42^{\circ} 32^{\prime} .78 \mathrm{~N}$ & $03^{\circ} 25^{\prime} .87 \mathrm{E}$ & $0.125 \pm 0.007 *$ & $0.091 \pm 0.005^{*}$ \\
\hline BL 3 & Lacaze-Duthiers open slope & FLUBAL 93 & 732 & $42^{\circ} 26^{\prime} .32 \mathrm{~N}$ & $03^{\circ} 40^{\prime} .26 \mathrm{E}$ & $0.182 \pm 0.009 *$ & $0.110 \pm 0.005^{*}$ \\
\hline G 1 & La Fornera open slope & FLUBAL 93 & 522 & $41^{\circ} 41^{\prime} .55 \mathrm{~N}$ & $03^{\circ} 31^{\prime} .56 \mathrm{E}$ & $0.087 \pm 0.009 * *$ & $0.063 \pm 0.007 * *$ \\
\hline EC 19 & Foix open slope & EUROSWAP 94 & 1121 & $41^{\circ} 01^{\prime} .66 \mathrm{~N}$ & $02^{\circ} 10^{\prime} .63 \mathrm{E}$ & & \\
\hline CN 38 & Foix open slope & CONCENTRA 93 & 977 & $40^{\circ} 59^{\prime} .30 \mathrm{~N}$ & $02^{\circ} 03^{\prime} .50 \mathrm{E}$ & $0.113 \pm 0.005^{* *}$ & $0.086 \pm 0.004 * *$ \\
\hline CN 36 & Foix canyon & CONCENTRA 93 & 861 & $41^{\circ} 04^{\prime} .60 \mathrm{~N}$ & $01^{\circ} 55^{\prime} .60 \mathrm{E}$ & $0.580 \pm 0.030^{* *}$ & $0.510 \pm 0.020 * *$ \\
\hline $\mathrm{T} 1$ & Foix canyon & FLUBAL 93 & 671 & $41^{\circ} 02^{\prime} .27 \mathrm{~N}$ & $01^{\circ} 59^{\prime} .45 \mathrm{E}$ & & \\
\hline EC 36 & Baleares open slope & EUROSWAP 94 & 653 & $40^{\circ} 15^{\prime} .02 \mathrm{~N}$ & $03^{\circ} 39^{\prime} .44 \mathrm{E}$ & & \\
\hline B1 & Baleares open slope & FLUBAL 93 & 597 & $40^{\circ} 14^{\prime} .11 \mathrm{~N}$ & $03^{\circ} 37^{\prime} .08 \mathrm{E}$ & & \\
\hline КТВ 30 & Baleares open slope & EUROMARGE 95 & 600 & $40^{\circ} 13^{\prime} .98 \mathrm{~N}$ & $03^{\circ} 36^{\prime} .77 \mathrm{E}$ & $0.085 \pm 0.004^{* *}$ & $0.068 \pm 0.003^{* *}$ \\
\hline EC 33 & Baleares canyon & EUROSWAP 94 & 1229 & $40^{\circ} 13^{\prime} .36 \mathrm{~N}$ & $03^{\circ} 29^{\prime} .94 \mathrm{E}$ & & \\
\hline KTB 27 & Baleares canyon & EUROMARGE 95 & 1200 & $40^{\circ} 13^{\prime} .02 \mathrm{~N}$ & $03^{\circ} 25^{\prime} .47 \mathrm{E}$ & $0.082 \pm 0.030^{* *}$ & $0.056 \pm 0.01 * *$ \\
\hline КTB 33 & Baleares margin & EUROMARGE 95 & 2070 & $40^{\circ} 27^{\prime} .31 \mathrm{~N}$ & $03^{\circ} 43^{\prime} .38 \mathrm{E}$ & & \\
\hline
\end{tabular}

\subsubsection{Carbonate distribution}

There was no major geographical variation in the carbonate contents $(22-30 \%)$ of sediments from the Gulf of Lions and Catalonian slopes. The carbonate content of the Balearic slope was found to be exceptional (higher than $45 \%$ to a $50 \%$ maximum); however, the core sampled at more than $2000 \mathrm{~m}$ water depth (KTB33) had an average content of $35 \%$ only (foure $3 a$ ).

Calcite was invariably the first component of the carbonate fraction (between 21 and $24 \%$ ) of the whole sediment). It is made of biogenic components (foraminifera and coccoliths) and inorganic micritic aggregates of terrestrial origin Giresse et al, 1996) Individual biogenic grains and the cemented aggregates are usually more or less generations of encrusting organisms. Aragonite was present in lower quantity $(<3 \%$ of the whole sediment) and was represented mostly by pteropods. The notable exception was the Balearic margin with an aragonite content ranging from 7 to $14 \%$ of the whole sediment. The lower sedimentary accumulation rates on the Balearic slope are unlikely to have affected carbonate concentrations. They have been interpreted as being a consequence of the virtual lack of fluvial input from the Islands Fornos and Ahr. 1997) and as a direct result of a primary carbonate production. Canals and Ballesteros
1997) showed an important modern production of carbonate particles by phytobenthic communities on the Mallorca-Menorca shelf but restricted at depths less than 85-90 m.

\subsubsection{Organic carbon distribution}

In the study area, total organic carbon (TOC) contents were lower than $1 \%$ (fgure $3 b)$. The values of the Gulf of Lions and Catalonian slopes $(0.6-0.9 \% \mathrm{dw})$ were always higher than those of the Balearic slope (0.5-0.6\%) except for the deeper site KTB33 (2 $070 \mathrm{~m})$. The highest concentrations were observed generally between 600 and $1200 \mathrm{~m}$ water depth. In various examples, the concentrations were markedly higher in the canyon axis than on the adjacent open slopes Buscail_and Germain, 1997; Buscail_et_al, 1997). But as already indicated for accumulation rates, this tentative conclusion was not systematically verified. High axis concentrations were observed mainly upstream in the canyon (500-1 $200 \mathrm{~m}$ water depths) and the open slope concentrations were higher downstream (figure 3 d). On the open slopes, TOC and water depth were correlated which suggests the predominant role of hydrodynamic processes in the concentration of the lightest particles, especially at higher depths than $600 \mathrm{~m}$. The same correlation between 

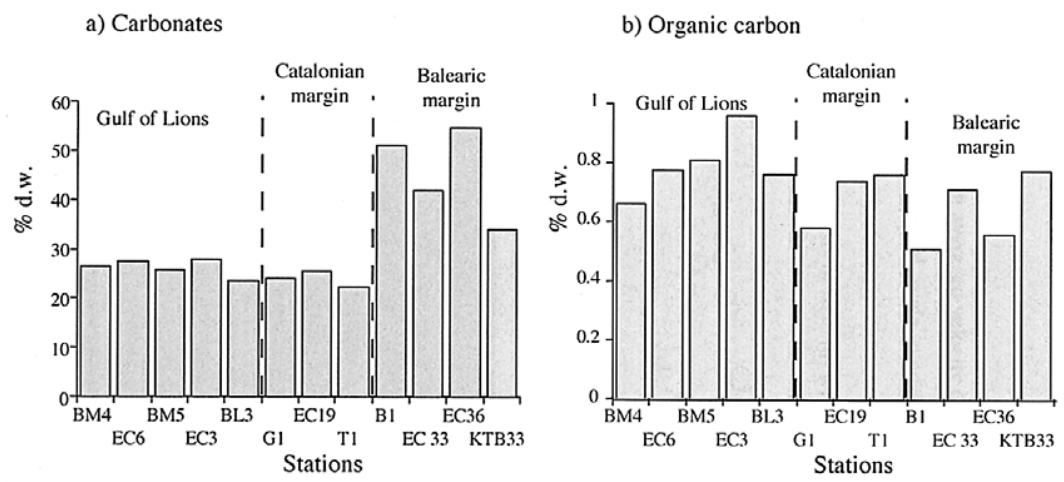

c) Hydrolysable carbon/TOC

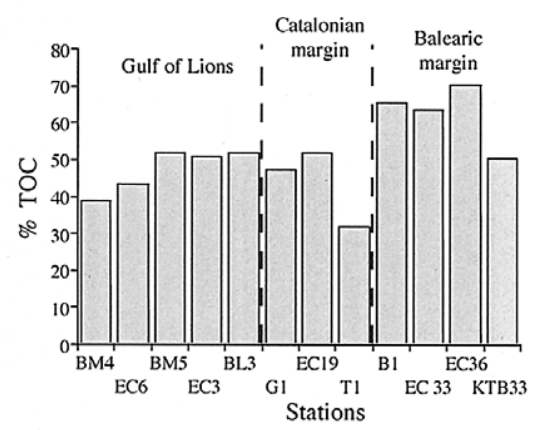

d) $\mathrm{C} / \mathrm{N}$

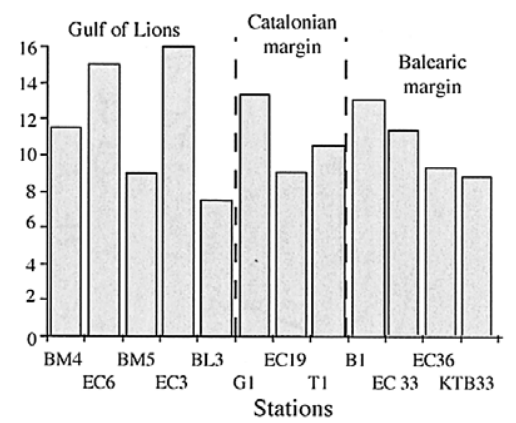

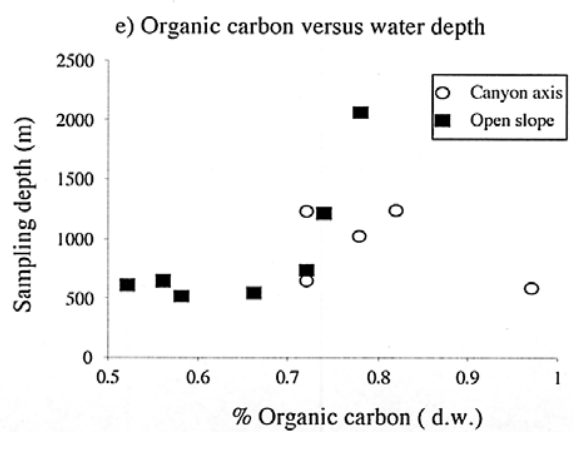

Figure 3. Distribution of carbonate (a), total organic carbon (b), hydrolysable carbon (c) contents and $\mathrm{C} / \mathrm{N}$ ratios (d) and organic carbon versus water depth (e) in the surficial sediments of the north-western Mediterranean margin.

water depth and TOC distribution was also observed in the Balearic slope.

Planktonic fluxes play an important role in concentrating hydrolysable carbon (HOC) in the Balearic slope sediments (> $60 \%$ HOC). Since terrestrial carbon inputs are higher, the northern slopes are characterized by lower concentrations (25-50\% HOC; foure 3 d). This terrestrial input is especially high in the Lacaze-Duthiers canyon (36\% HOC in the axis and $43 \%$ HOC on the open slope). Planktonic production is also high in the LacazeDuthiers canyon. The budget implies perhaps a differen- tial decay of organic matter in sea-water: plankton is mainly composed of diatoms and coccoliths in the Lacaze-Duthiers area and is characterized by dinoflagellate abundances off the Baleares Chrétiennot-Dinet 1996.

In contrast, the $\mathrm{C} / \mathrm{N}$ ratio, despite some anomalously high or low values, was higher on the Gulf of Lions and Catalonian slopes $(\mathrm{C} / \mathrm{N}>12)$ than on the Balearic slope (figure $3 d$ d). In the latter, the distal input from landmass contributes less to sediments than planktonic fluxes and therefore more nitrogenous matter is found. 


\subsection{Hemipelagic-dominant deposition}

Mud represented over $95 \%$ of the lithofacies in four core sections. This homogeneous deposit presented evidence of beginning early diagenesis of organic matter. The examples showed no significant localization of early diagenetic facies neither physiographic nor bathymetric. However, only, core BM4 showed some evidence of gravity deposits.

- Core EC6. The site is located in the axial zone of the Lacaze-Duthiers canyon at a water depth of $1015 \mathrm{~m}$, near the lower boundary of the canyon depocentre. The muddy sediment accumulation rate was estimated to be $0.112 \pm 0.010 \mathrm{~cm} \cdot \mathrm{yr}^{-1}$ table regular with a break observed between 17 and $19 \mathrm{~cm}$ where the sand contents increased. These sandy layers were characterized by large quantities of benthic foraminifera from the outer shelf (E. crispum and mainly altered Miliolidea) (fgure 4d). Except for this localized episode characterized by lower values of the $\mathrm{C} / \mathrm{N}$ ratio, TOC and HOC decreased regularly downcore which is consistent with the burial process.

- Core EC19. This core was collected from a deep open slope (1 $221 \mathrm{~m}$ water depth) east of the Foix canyon where uniform muddy deposition prevails with a sand weight percentage between 2 and $5 \%$. In spite of a small and nearly parallel increase in carbonate and sands below
$15 \mathrm{~cm}$, the lithology of this deposit can be considered as uniform (figure $4 b$ ). Indicators of the reworking of shallow water relict sediments from the outer shelf such as weathered Miliolidea and coarse vegetal debris were rare, which is consistent with minimal gravity-induced processes. TOC and HOC decreased progressively in parallel which indicates clearly an early diagenetic effect during burial processes. As in core EC6, the highest TOC content was observed in the uppermost centimetres. $\mathrm{C} / \mathrm{N}$ ratio range from 5.3 to 9.6 and the highest values were consistently located in the lowermost levels. In the same open slope, the mean sedimentation rate was estimated to be $0.113 \pm 0.005 \mathrm{~cm} \cdot \mathrm{yr}^{-1}$ for the near $\mathrm{CN} 38$ station table .

- Core T1. This core was collected from the eastern wall of the Foix canyon at a 671-m water depth. It was made of a muddy and unstructured accumulation. Its sandy fraction, which did not vary very much, ranged from 1.2 to $2.2 \%$ in the upper part of the section and was correlated with a slight upward decrease in carbonates (figure 5d). In this case, indicators of gravity-driven processes are small oxidized aggregates and shallow water foraminifera such as E. crispum. They were found throughout the entire section but without any evidence for significant vertical variation. TOC and HOC decreased progressively with burial depth. Episodic processes (between 14 and $16 \mathrm{~cm}$ ) corresponded to coarse vegetal
Figure 4. Detailed log crosssections showing sandy fraction, carbonate, total organic carbon, hydrolysable carbon/TOC contents, $\mathrm{C} / \mathrm{N}$ ratio and various tracers of gravity-driven processes in cores EC6 (a) and EC19 (b) where hemipelagic sedimentation prevail. The dashed line corresponds to the oxic-anoxic boundary (O.A.B.).
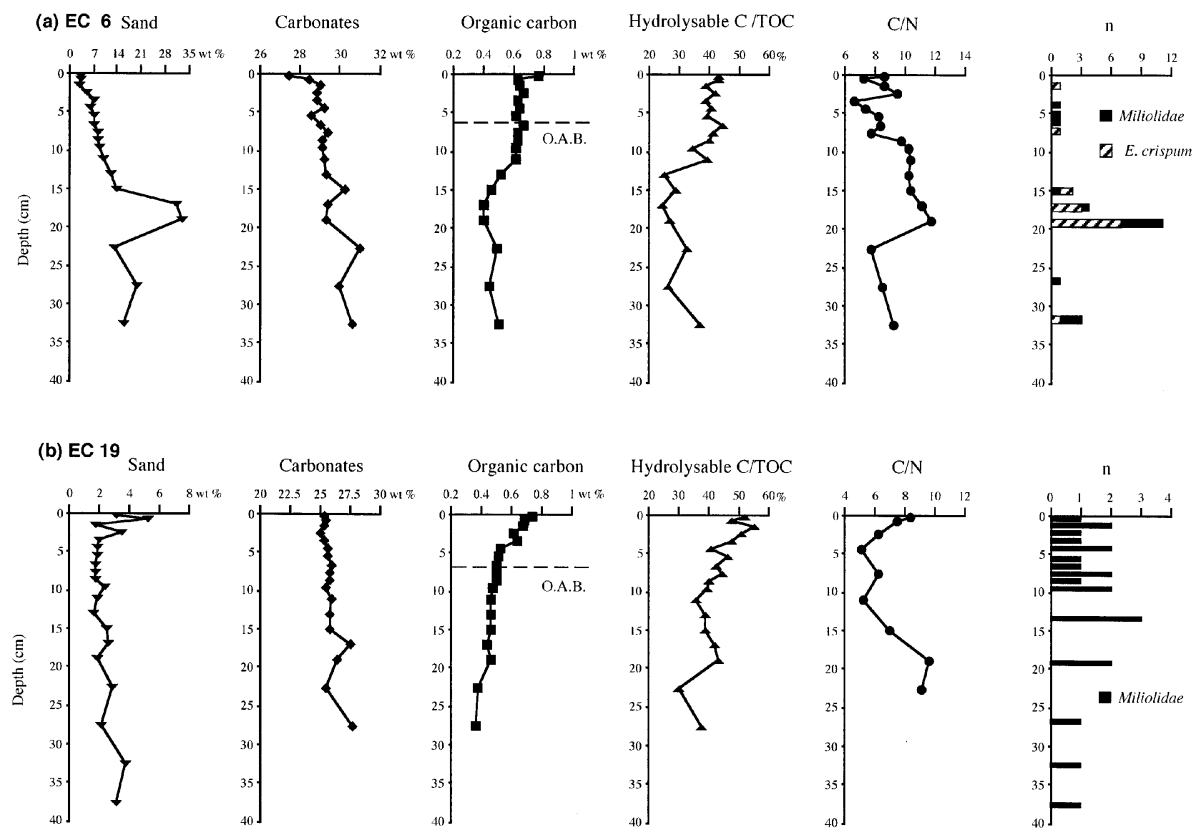
debris made of a probably more hydrolysable matter. We attributed the variability of the $\mathrm{C} / \mathrm{N}$ ratio ranging from 8 to 13 to these vegetal debris occurrences. They were exceptional and never indicated a gradual change in the depositional processes. In this same canyon, a linear sedimentation rate was estimated at $0.580 \pm$ $0.030 \mathrm{~cm} \cdot \mathrm{yr}^{-1}$ for the near CN 36 station.

- Core BM4. The site is located in the eastern open slope of the Planier canyon at $550 \mathrm{~m}$ water depth (figure $5 \mathrm{~b}$ ). The sediment accumulation rate was estimated to be $0.144 \pm 0.007 \mathrm{~cm} \cdot \mathrm{yr}^{-1}$ (table $)$ and essentially consisted of mud. The major decrease in the excess ${ }^{210} \mathrm{~Pb}$ activity matched with higher sand contents around $15 \mathrm{~cm}$ depth core. Another high sand concentration layer in the lower part $(15-30 \mathrm{~cm})$ of the core was used to infer additional discharge of gravity-induced input derived from the outer shelf. Oxidized particles, glauconitic infillings, gypsum crystals, oxidized worm tubes and diversely altered Milliolidea are the tracers of this process. Carbonate (26-28\%) and sands (5-10\%) varied moderately throughout the core reflecting that gravity transport events were few during the deposition of the basal part. From these patterns, deposition was inferred to have been dominated by advective input. If they correspond to a mixture of hemipelagic and gravity induced deposition, the last was too moderate to induce significant transformation of the organic matter distribution. TOC and
HOC contents decreased almost regularly downcore. Several occurrences of burrow filling appeared slightly elevated relative to surrounding sediments $(0.083 \pm$ $0.004 \mathrm{~g} \cdot \mathrm{cm}^{-2} \cdot \mathrm{yr}^{-1}$ ) and may account for some irregularities of the curves. Despite some peaks related to the occurrence of coarse vegetal debris, the $\mathrm{C} / \mathrm{N}$ ratio appeared to be almost constant. In the upper $15 \mathrm{~cm}$, small sulphurous balls and scoriae products of the aluminium metallurgy were found thus representing approximately the last deciennal accumulation.

\subsection{Dominant gravity-induced deposition}

The most typical examples of gravity-induced deposition have been recognized in various geographic and physiographic sites: upstream and downstream canyon axes and open slopes, Gulf of Lions and Catalonian margins. - Core BM5. This core was collected from the deep axis (1 $250 \mathrm{~m}$ water depth) of the Planier canyon. In contrast with a nearly constant carbonate concentrations (26-30\%), sand distribution was characterized by a content decreasing regularly from the sediment-water interface (7\%) to $38 \mathrm{~cm}$ depth (2\%). This granulometric trend was enhanced in the upper part of the core by the addition of 'red muds' derived from the bauxite treatment since 1967 Chamley, 1971. Red muds were
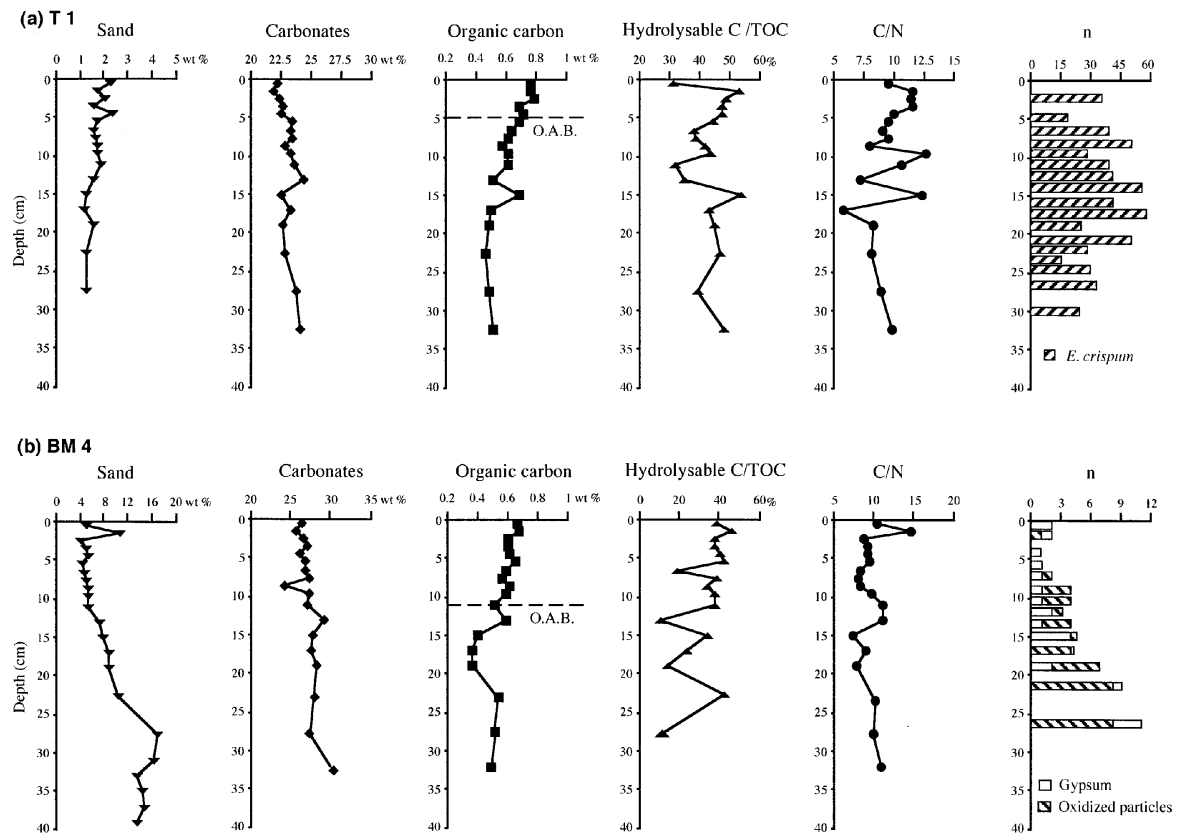

Figure 5. Detailed log crosssections showing sandy fraction, carbonate, total organic carbon, hydrolysable carbon/TOC contents, $\mathrm{C} / \mathrm{N}$ ratio and various tracers of gravity-driven processes in cores T1 (a), BM4 (b) where hemipelagic sedimentation prevail. The dashed line corresponds to the oxic-anoxic boundary (O.A.B.). 
present mostly in the upper $5 \mathrm{~cm}$ which gives an overall red appearance. They were associated with aluminous or sulphurous scoriae and carbonized debris. Deeper presence was derived from biological reworking. The occurrence of coarser deposits in the lower part was driven and fed by gravity-induced supply as suggested by the abundance (figure 6d) of preserved or altered tests of Miliolidae in which micropores along the inter-fibre boundaries transform initial fibres into piles of sub-crystals. $E$. crispum, A. beccarii (sometimes oxidized, ferruginous sandstones and glauconitic moulds) are the other outer shelf derived particles. TOC decreased gradually with depth sometimes irregularly. HOC decreased in parallel. Apparently the $\mathrm{C} / \mathrm{N}$ ratio did not follow the trend: its highest values were recorded between 22 and $28 \mathrm{~cm}$ where gravity tracers (E. crispum, oxidized tests, glauconite) increased substantially (near $9 \mathrm{~cm}$ the $\mathrm{C} / \mathrm{N}$ peak is correlated with E. crispum abundance, and near $2 \mathrm{~cm}$, with oxidized tests). In the uppermost $10 \mathrm{~cm}$, the curve was altered by the coal debris of the red muds.

- Core BL3. The site corresponds to the open slope between Lacaze-Duthiers and Pruvost canyons at a 730-m water depth. This core contained only small amounts of sands (1-2\%) and carbonates (24-26\%), both homogeneously distributed alongcore (fgure $6 \mathrm{~b}$ ). A rather regular gradient in ${ }^{210} \mathrm{~Pb}$ activity lead to a relatively high sedimentation rate of $0.182 \pm 0.009 \mathrm{~cm} \cdot \mathrm{yr}^{-1}$ (table - A). The tracers of shallow water relict deposits derived from the outer shelf (Miliolidea, A. beccarii, glauconitics fillings) were observed throughout the section. The $0-15-\mathrm{cm}$ deposit showed significant evidence of oxidized particles (small sandstone fragments, worm tubes) and ligneous debris. The latter can explain the parallel maxima of TOC and HOC up to $10-15 \mathrm{~cm}$ depth although previous analyses had emphasized a general upcore gradient. Ligneous debris induced most probably the increase of the $\mathrm{C} / \mathrm{N}$ ratio at the same levels. This site is protected from sand inputs and characterized by uniform advective transport. The gravity-induced supply of the last sedimentary episode is obvious from the linkage between organic matter parameters and sand composition.

- Core EC3. Sediment was collected from the head of the Lacaze-Duthiers canyon (590 m water depth) where the accumulation rate $0.125 \pm 0.007 \mathrm{~cm} \cdot \mathrm{yr}^{-1}$ was found to be lower than that of Core BL3 $\left(0.182 \pm 0.009 \mathrm{~cm} \cdot \mathrm{yr}^{-1}\right)$ (table - This physiographic position could explain the more significant contrast in sand content which was approximately $50 \%$ in the lowest levels and decreased to about $7 \%$ in the uppermost sediment (figure 7 d). This change implies that the conditions of sedimentation were significantly different. Gravity-driven flow during the deposition of the lower part of the core was indicated by the abundance of Miliolidea, sandstone fragments and
Figure 6. Detailed log crosssections showing sandy fraction, carbonate, total organic carbon, hydrolysable carbon/TOC contents, $\mathrm{C} / \mathrm{N}$ ratio and various tracers of gravity-driven processes in cores BM5 (a) and BL3 (b) where mixed sedimentation hemipelagic and gravity-driven prevail. The dashed line corresponds to the oxic-anoxic boundary (O.A.B.).
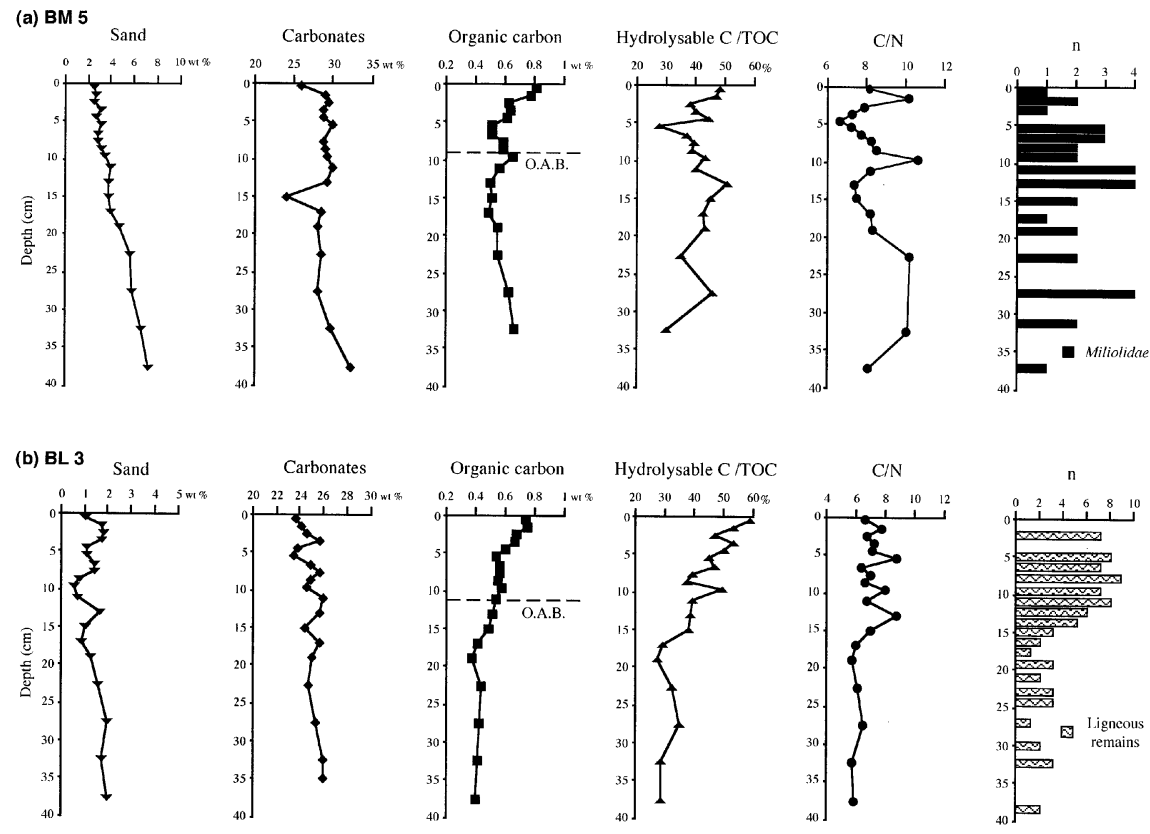
mainly glauconitic grains. However, these tracers were still observed in the uppermost $10 \mathrm{~cm}$. The vertical trend of the grain size can be related to the TOC upcore increase from 0.3 to $1 \%$, emphasizing the usual vertical diagenetic gradient. Despite slight irregularities, HOC contents supported the same interpretation. The $\mathrm{C} / \mathrm{N}$ ratio showed in the uppermost part various interferences between evolved and less evolved organic matter.

- Core G1. The sediment core was obtained from the SW open slope of the Fornera canyon at $522 \mathrm{~m}$ water depth. According to its distance from the axial channel, the apparent accumulation rate was moderate, $0.087 \pm 0.09 \mathrm{~cm} \cdot \mathrm{yr}^{-1}$, and mixing was present up to depth core of $10 \mathrm{~cm}$. In contrast with core BL3, sand concentration was higher in the upper half of the section with an increase from 12-14 to 16-20\% (Ggure 7b). This trend is consistent with an increasing supply of grains reworked from the outer shelf: Miliolidea with both a 'chalky' or porcellaneous surface, A. beccarii and some spiralled oogonia of Charophyta more or less calcitized. We noted that carbonates decreased from 28 to $24 \%$ as sand concentrations increased. Organic carbon (TOC and HOC) showed the usual downcore decrease, and the $\mathrm{C} / \mathrm{N}$ ratio seemed to follow the same trend, increasing from 9-10 to $12-15$ in the uppermost sediments. Various levels $(0-1,2-3,4-5,5-6$ and $7-8 \mathrm{~cm})$ were relatively enriched in various ligneous or coaly debris. This upper part of the core was also characterized by a relative rarefaction of amino acids (Buscail and Germain. 1997) which could be related to mixing. In each of these four examples of dominant gravity-induced deposition, more evolved organic matter contradicts the normal degradation gradient with burial depth. We do not recognize any gravity induced input of less evolved organic matter as it was found on the Petit-Rhône deep-sea fan Buscail et al. 1997.

\subsection{Northern Balearic slope deposition}

The entire slope is characterized by the lowest sediment accumulation rates of the study area. This situation provides ideal conditions for analysing early diagenesis. - Core B1. This core was taken from $597 \mathrm{~m}$ water depth. Its sedimentation rate can be estimated to about $0.085 \pm 0.004 \mathrm{~cm} \cdot \mathrm{yr}^{-1}$, similar i.e. to the rate of the adjacent core KTB30 (600 m water depth) (table 1 ). The sand fraction was completely composed of biogenic particles in which planktonic foraminifera and pteropod debris are more abundant than benthic tests (peaks at 4-5 and $12-14 \mathrm{~cm}$ corresponding to worm tube accumulations) (fgure 8a). This sand fraction did not contain any quartz grain which explains the high carbonate concentrations, approximately double those of the northern
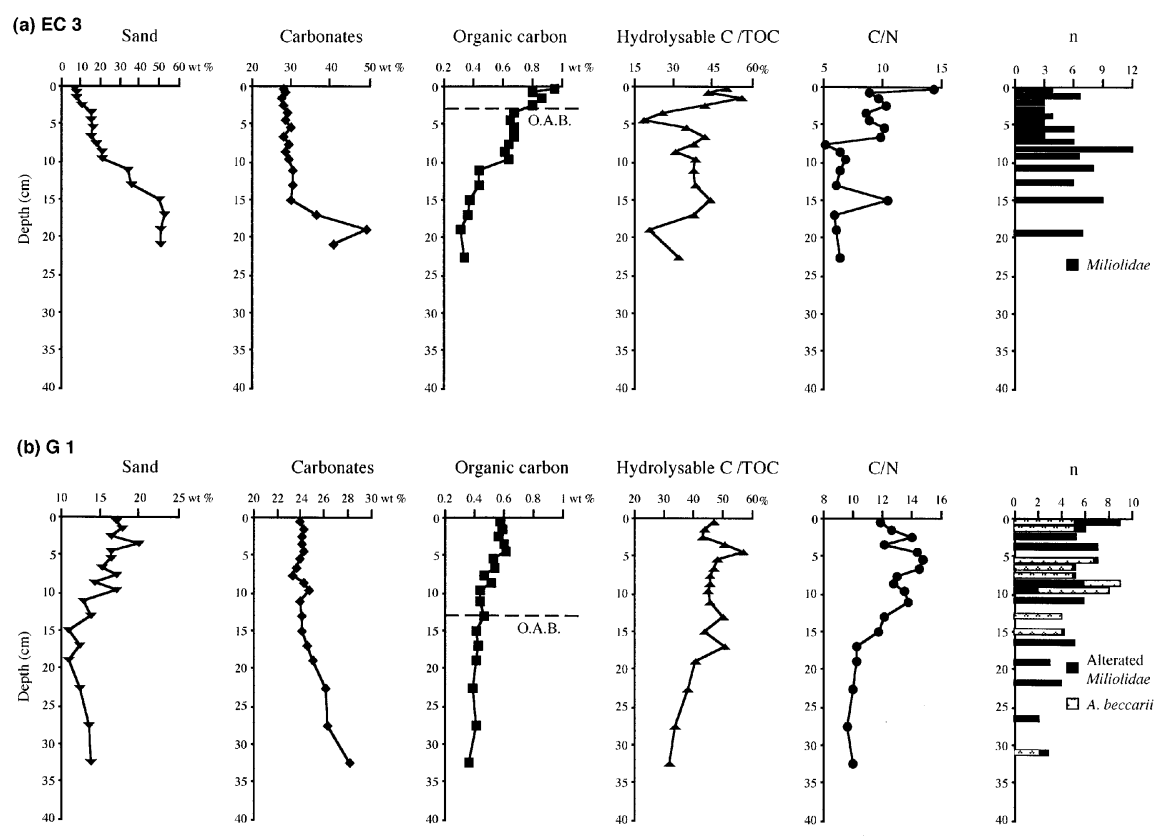
Figure 7. Detailed log cross- sections showing sandy fraction, carbonate, total organic carbon, hydrolysable carbon/TOC con- tents, $\mathrm{C} / \mathrm{N}$ ratio and various tracers of gravity-driven processes in cores EC3 (a) and G1 (b) where mixed sedimentation hemipelagic and gravity-driven prevail. The dashed line corresponds to the oxic-anoxic boundary (O.A.B.).


slopes. The carbonate curve presented increasing contents in the lower half of the core, then stabilized from $16 \mathrm{~cm}$ to the surface. Some rare altered miliolids, some calcite or dolomite rhomboedrons and some glauconitic moulds indicated episodic gravity-induced events, but this carries a low statistical weight. Neither red algal debris, nor other skeletal allochems derived from the carbonate ramp of the Balearic Island [Fornos and Ahr. 1997) were observed. During this regular slow pelagic deposition, early diagenesis of the organic matter leads to a burial process, characterized by a downcore decrease of TOC and inversely a downcore increase of the $\mathrm{C} / \mathrm{N}$ ratio. $\mathrm{HOC}$ seems abundant and rather stable related to a permanent planktonic flux containing numerous dinoflagellates (Chrétiennot-Dinet, 1996) In the muddy fraction $(<50 \mu \mathrm{m})$ of the entire core, the homogeneity of the clayey assemblage and the quartzeous silts appeared to be the result of poor terrestrial transfer and gravity-induced transport.

In Core B1, the gradual downward increase of carbonate content posed a problem. A dissociation and possibly a dissolution of aragonitic prisms of pteropod tests can be observed in the uppermost levels (figure 2e). Under low accumulation conditions, preferential solution occurred in the 12-13 uppermost pink or light red centimetres in which oxidation of organic matter and sulphides induces acidity. Downcore sulphate reduction leads to the produc- tion of pyrite. This increase in alkalinity, commonly observed, can allow precipitation of carbonate minerals. In the lower levels of the core, we observed micritic aggregates infilling the cavities of ostracod, pteropod or globigerine tests (figure 2A), some of them reaching 60 to $80 \%$ of calcite (microprobe analysis).

- Core EC36. The site of this core (653 m water depth) is near to that of core B1. Consequently, the accumulation rate can be estimated of the same order than the adjacent KTB30: $\sim 0.085 \pm 0.004 \mathrm{~cm} \cdot \mathrm{yr}^{-1}$. Most of the analytical profiles (figure $8 b)$ of this core were comparable with those of the previous one. The sand fraction distribution was relatively uniform and was dominated by pelagic tests (globigerine, orbuline and pteropod). There is no evidence of quartz grains which is consistent with the general lack of terrestrial inputs. Preserved or altered miliolids were observed in small and slightly variable amounts corresponding to less gravity transport. Some scoria were noted in the uppermost $9 \mathrm{~cm}$ and interpreted to represent tracers of the modern industrial activity (aeolian fluxes or boat pollution). Carbonate content was relatively high, and similarly to that of core B1, presented a downcore increase (from 54 to $68 \%$ ). Diagenetic dissolution and probable precipitation processes of carbonate were recognized by SEM analysis (fgure 2e,f). The three curves corresponding to organic matter showed roughly the same diagenetic patterns: downcore decrease
Figure 8. Detailed log crosssections showing sandy fraction, carbonate, total organic carbon, hydrolysable carbon contents, $\mathrm{C} / \mathrm{N}$ ratio and various tracers of gravitydriven processes in cores from the northern Balearic slope: B1 (a) and EC36 (b). The dashed line corresponds to the oxic-anoxic boundary (O.A.B.).
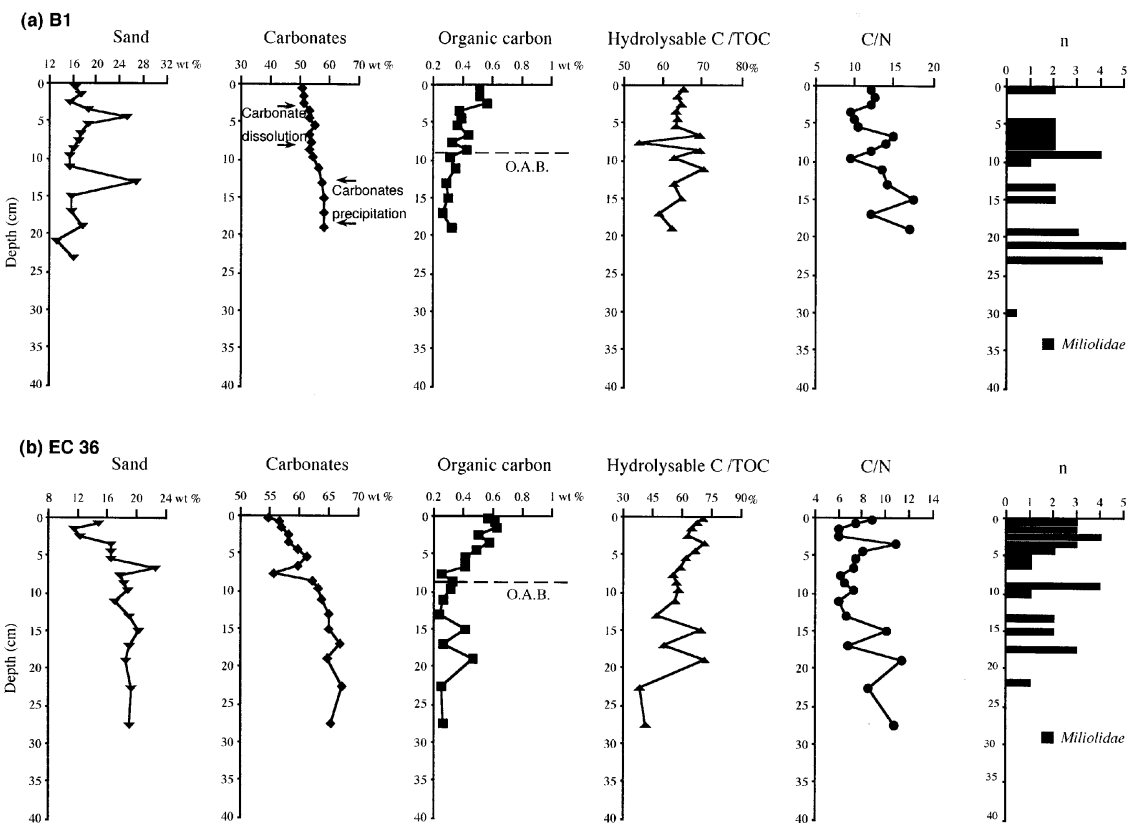
of TOC and $\mathrm{HOC}$ and increase of the $\mathrm{C} / \mathrm{N}$ ratio. Although organic profiles were quite similar, the EC36 core presented higher HOC contents (to $72 \%$ ) and a lower $\mathrm{C} / \mathrm{N}$ ratio $(<12)$ than core $\mathrm{B} 1$, which may be explained by the higher planktonic flux rate (Chrétiennot-Dinet. 1996).

- Core EC33. At a 1229 -m water depth, this core was collected at mid-slope. Its accumulation rate was assumed to be close to the $0.082 \pm 0.030 \mathrm{~cm} \cdot \mathrm{yr}^{-1}$ of the adjacent core KTB27 (table ). At this depth, carbonate and sand contents exhibited comparatively lower values than the two shallower previous sites and a slight increased in the $\mathrm{C} / \mathrm{N}$ ratio (fgure $9 d$ ). The sand contents were nearly constant (5 to $8 \%$ ) but appeared to increase upwards almost linearly with carbonate contents (the benthic foraminifera present were very peculiar). The lack of quartz grains and the scarcity of particles derived from the shelf (few altered or oxidized miliolids) led to ruling out any consequent gravity-driven process. In these conditions of low accumulation rate, the early diagenesis of organic matter was consistent with a burial process expressed by a downward decrease of TOC and increase of the $\mathrm{C} / \mathrm{N}$ ratio. An early diagenetic dissolution/ precipitation event of carbonates was observed: the boundary between upward oxidizing conditions and alkaline sulphate reduction was located around $12 \mathrm{~cm}$.

- Core KTB33. This core is the deepest of the study (2 $070 \mathrm{~m}$ water depth). It is located on the glacis of the
Balearic margin. The accumulation rate was presumed to be very low, $1-2 \mathrm{~cm}$ per 100 years according to $\mathrm{ZuO}$ et al_(1997) but has not been determined. The lithological trend which appeared at mid-slope was well developed: low sand $(4 \%)$, and carbonate contents $(35 \%)$ and relatively higher TOC concentrations $(0.4-0.8 \%)$ in the upper $12 \mathrm{~cm}$ (figure 9b). This lithological composition may have been the product of distal fluxes from the Ebro margin of eastern Spain Morris et al, 1998) mechanism that involves the rotation Liguro-Provencal Current. After a long sorting, the terrestrial input was mainly composed of a mixture of clay minerals and quartzeous silts whereas the sand fraction included exclusively globigerine and pteropod tests. Benthic species were nearly absent, quartz grains were very scarce, and no particles derived from the shelf were found. As in core EC36, some scoriae and coaly debris were found in the uppermost 6-7 $\mathrm{cm}$. With slow accumulation, burial diagenesis took place in specific conditions. TOC and HOC decreased downward throughout the core (except $12-14 \mathrm{~cm}$ level), and the $\mathrm{C} / \mathrm{N}$ ratio increased substantially only below $17 \mathrm{~cm}$. Carbonate content increased below this depth which corresponds to the oxic-anoxic boundary. Just above $(12-16 \mathrm{~cm})$, brown levels of ferromanganese oxides (up to $60 \% \mathrm{Mn}$ ) precipitated on globigerine tests. This vertical distribution of $\mathrm{MnO}_{2}$ is very similar to the one in a core sampled in the
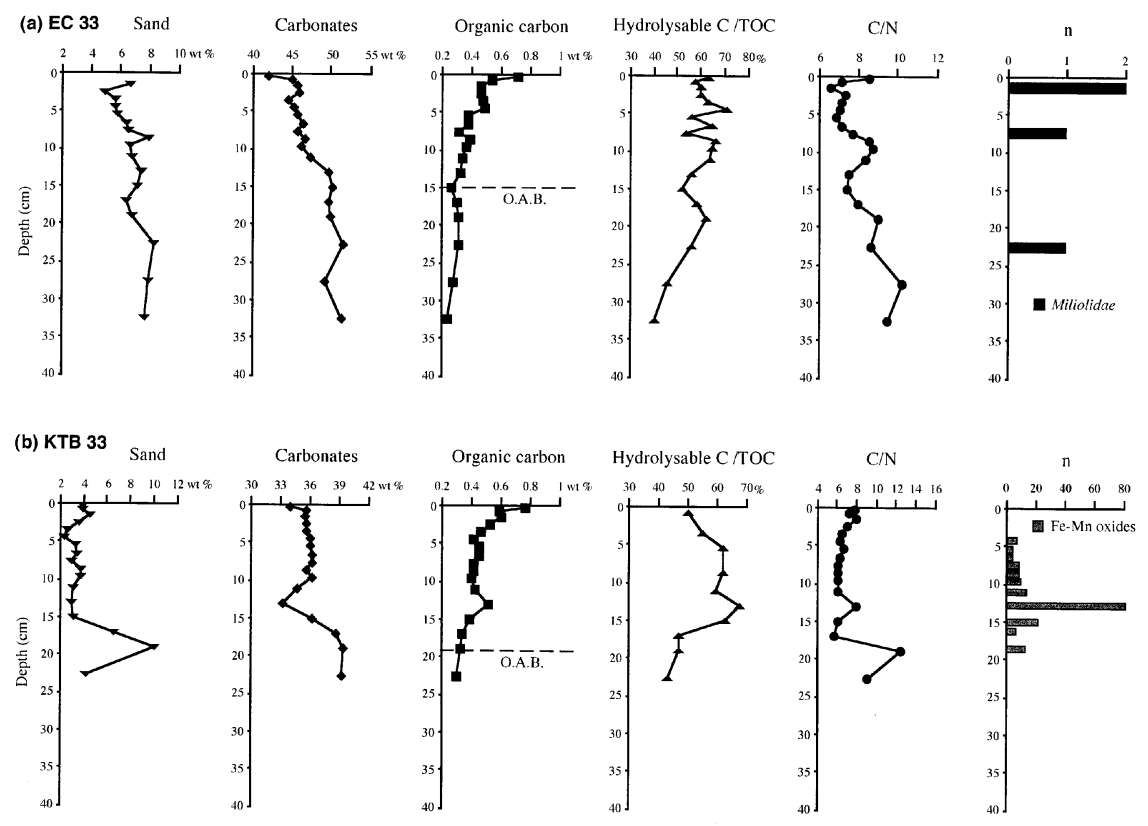
Petit-Rhône deep-sea fan around $2300 \mathrm{~m}$ Buscailet_al. 1997) and to those sampled in the deep-sea fans of the Sète canyon, the grand Rhône canyon, and the Planier canyon Marin and Giresse, 2001). As for the shallower sediments of this slope, the lowest content in carbonate above $15 \mathrm{~cm}$ implies dissolution processes, but in this case, the concentration in the lower part of the core may reflect enhanced pteropod productivity and not a diagenetic effect. The $\mathrm{C} / \mathrm{N}$ ratio was low suggesting a correlation with planktonic productivity throughout the core.

\section{DISCUSSION AND CONCLUSION}

\subsection{Implications of the lithologic vertical changes on the north-western Mediterranean slope: gradual processes and accidental events}

The vertical changes of deposition were interpreted to have been caused by the interference between accidental processes in which the geographic or physiographic factors appear to play a secondary role. Some open slope sites, for example, were essentially the centres of gravitydriven sedimentation and/or accumulation. Canyon axes, by contrast with the presumed model, exhibited an uniform sedimentation possibly of low rate. The influence of the involved parameters will be considered for each component.

- Sands. At the present time of high sea level and at a distance of several kilometres from the coast and river mouths, slope-scale accumulation is generally controlled by advective flux and characterized by muddy facies. A muddy facies has been identified in most of the sites and characterized by a very low sand content: EC6 (4\%), EC19 (3\%), T1 (2\%), BM4 (5\%), BM5 (2\%), BL3 (2\%), EC3 (2\%) and G1 (11\%). The minor sand fraction consists essentially of biogenic fragments, foraminifera tests, and in some cases, quartz and vegetal debris. An increase of sand content is therefore indicative of inputs by gravity-induced processes as reflected by the deposition of various tracers derived from the outer shelf. The occurrences recorded have a variable degree of significance: the lower part of core BM4 (open slope) with a sand increase from 5 to $15 \%$, core BM5 (canyon) with a rise from 2 to $7.5 \%$, core EC3 (canyon) with a shift from 7 to $50 \%$ and core G1 (open slope) with values increasing from 11 to $18 \%$. This relationship sand-gravity process has not been recorded in core BL3 (canyon) where it is only indicated by various biogenic or geochemical tracers without any sand-size variation. This is most likely due to downslope transfer of the coarser grains, but this cannot be determined. On the Balearic slope, sand compositions are all similar. Pelagic and benthic foraminifera on the upper slope, and pelagic foraminifera on the lower slope, are the major constituents. These compositions are consistent with the scarcity of gravity-induced transport concomitant with low terrestrial input which enhance relatively high planktonic fluxes. The terrestrial silicoaluminous input increases with water depth and closer to the trough of the Valencia gulf: sand percentages regularly decrease downslope: $12 \%$ at $597 \mathrm{~m}, 15 \%$ at $653 \mathrm{~m}, 7 \%$ at $1299 \mathrm{~m}$, and $4 \%$ at $2070 \mathrm{~m}$.

- Carbonates. Carbonate contents correspond to the analysis of total sediment. Pelagic foraminifera in the $>50-\mu \mathrm{m}$ fraction, tests fragments between 12 and $50 \mu \mathrm{m}$, coccoliths between 2 and $4 \mu \mathrm{m}$, and micritic aggregates between 0.1 and $5 \mu \mathrm{m}$ (sometimes 10 to $15 \mu \mathrm{m}$; Giresse et al. 1996) define this carbonate fraction. The northern slope of the studied area commonly contained percentages between 20 and $30 \%$ with (off the Rhône river mouth) a micritic component reaching 25 to $50 \%$ locally. On the slopes, vertical changes corresponded only to less than $10 \%$ of the total carbonates and were not related to any paleogeographical event. In this context, it is important to consider the concomitant increase of carbonate (mostly testaceous) and sand contents during 'gravity' intervals. Our data show that carbonate percentage increases in various ways: from 28 to $32 \%$ in the lower part of BM5, from 29 to $50 \%$ in the lower half of EC3, from 24 to $28 \%$ in the lowest levels of G1. As for sands, BL3 did not provide any signal. On the Balearic slope, the highest contents of the region reflected even less terrestrial input than development of primary production. The most significant feature of carbonate distribution was the widespread downcore increase of the contents, especially below the oxic-anoxic boundary.

- Organic matter. Organic matter is known to be diagenetically transformed during gradual burial. Frequently, an exponential decrease gradient was related to the oxidized layer thickness Buscail et al. 1997). A downcore decrease of TOC was recorded in all cores where advective supply was dominant (EC6, EC19, T1, BM4). This decrease was recorded in cores in which platform derived gravity flows were active but not strong enough to hide the diagenetic effect (BM5, EC3, BL3 and G1). 
This downcore decrease was maximum in the low accumulation area of the Balearic cores, in which up to $50 \%$ TOC disappeared over the upper $15 \mathrm{~cm}$ (B1, EC36) or $10 \mathrm{~cm}$ (EC33 and KTB33).

The labile fraction of carbon (HOC) commonly presents the same decreasing gradient, with or without gravity transport interference. Between 10-20 cm, HOC varied from 30 to $50 \%$. But in some cores, the burial-diagenetic trend was more discontinuous and presented peaks at various deep layers $(25 \mathrm{~cm}$ in T1, $22 \mathrm{~cm}$ in BM5, $15 \mathrm{~cm}$ in EC3). This implies at least that some intervals correspond presumably to increased sedimentation rate. The highest HOC values were obtained on the Balearic slope where a 40-45 \% loss can be estimated for a burial depth of $20-25 \mathrm{~cm}$. The only exception was found in core B1 with a relative stable content along the $30 \mathrm{~cm}$. However, this observation was not supported by neither TOC nor $\mathrm{C} / \mathrm{N}$ profiles. The expected downcore decrease of the $\mathrm{C} / \mathrm{N}$ ratio is typically absent in all sections of the Gulf of Lions and Catalonian slopes. The discrepancy is probably the result of two factors at least i) a relatively high sediment accumulation rate $\left(0.1-0.6 \mathrm{~cm} \cdot \mathrm{yr}^{-1}\right)$, ii) various gravityinduced input leading to either the association with degraded organic matter throughout the section or an inverse gradient in its upper part (BM5, BL3, G1). When the accumulation rate is low $\left(<0.1 \mathrm{~cm} \cdot \mathrm{yr}^{-1}\right)$, burial depth is the controlling parameter of the $\mathrm{C} / \mathrm{N}$ ratio downcore increase on the Balearic slope. This ratio increased more around $20-25 \mathrm{~cm}$. The amplitude of this increase depended markedly on the water depth conditions of deposition, ranging by a factor of 4 to 5 at mid-slope, and of 7 in the lower part of the slope.

\subsection{Diagenesis of the northern Balearic carbonate: evidence for decoupling of diagenesis and mechanical accumulation}

Carbonate contents which were found to be significantly higher in the lower than in the upper part of the cores cannot reflect the effects of biological productivity or depositional environmental changes.

The relationship between sulphate reduction and saturation indices was modelled for carbonate minerals Stoes sel, 1992). Carbonate dissolution results from the transformation of iron oxides to iron sulphides. Model results generally indicate that carbonate saturation decreases during oxic respiration due to the release of carbonic acid and increases during sulphate reduction due to an increase in alkalinity (Tribble, 1993). Consequently, relatively open systems in which oxic respiration dominate organic diagenesis have the potential to dissolve aragonite by the input of weak acids as $\mathrm{H}_{2} \mathrm{CO}_{3}$ and $\mathrm{H}_{2} \mathrm{~S}$ Similarly, the decomposition of material with a high $\mathrm{C} / \mathrm{N}$ (depleted in $\mathrm{N}$ ) ratio results in setting the system at a lower aragonite saturation state than it would be for material with a low $\mathrm{C} / \mathrm{N}$ ratio. This reaction has been widely recognized in continental slope sediments that are relatively rich in organic matter. In this study, the B1 section with a $>0.4-0.5 \mathrm{wt} \%$ TOC presented at about $15 \mathrm{~cm}$ depth a downcore $\mathrm{C} / \mathrm{N}$ ratio increase related to a downcore carbonate content increase. SEM observation suggested that the alteration of aragonitic tests (figure 2el) was more developed in the upper oxidized levels. FeS minerals appear to have a strong effect on aragonite saturation state, but the model results indicate that sedimentary environments rich in iron tend towards aragonite over-saturation whilst iron poor system do not (Tribhle, 1993). In this study, pyrite was widespread in the lower parts of the cores and associated with the highest carbonate values. All the levels had bulk iron contents in the range of 2 to $3 \%$. The slow sedimentation rates observed were reflected by the exceptional thickness of the pink oxic layer (up to $20 \mathrm{~cm}$ ) in which under-saturation of carbonate and especially of aragonite is suspected. In addition, it is reasonable to expect the effectiveness of sulphate reduction for producing carbonate precipitation.

The saturation levels in the Mediterranean are globally higher than those at comparable depths and latitudinal position in the Atlantic (Millero et al, 1979). The near-surface seawater is supersaturated with respect to $\mathrm{CaCO}_{3}$, but organic compounds prevent the precipitation of calcium carbonate (Wegrzynek et al, 1997). In the semi-enclosed eastern Mediterranean sea, a considerable amount of the calcium-carbonate is precipitated inorganically. Magnesium calcite $\left(10-11\right.$ mole $\left.\% \mathrm{MgCO}_{3}\right)$ is present, generally comprising from 15 to $40 \%$ of the total carbonate Milliman and Miiller_1973). This sporadic phenomenon may be connected with low or nondepositional environment. In the western Mediterranean, Van_Straaten (1966) stated that calcite cementation was caused by the interstitial dissolution aragonite, and the subsequent removing of overlying sediment (mechanical processes): the pore-waters exposed to bottom waters are supersaturated and carbonate precipitates. Because of the 
early diagenetic decay of the organic matter into the top layers, the consequent decrease of $\mathrm{pH}$ induces a partial dissolution of carbonates and then a precipitation in the deeper layers (Bodur and Ergin. 1994). In our case, pore-water was not analysed. Carbonate dissolution in the oxic layer and carbonate precipitation in the anoxic layer can be assumed. Below the oxic-anoxic boundary, micritic fillings or coatings were observed below $15 \mathrm{~cm}$ at $597 \mathrm{~m}$, below $9 \mathrm{~cm}$ at $653 \mathrm{~m}$, near $13 \mathrm{~cm}$ at $1229 \mathrm{~m}$, and near $17 \mathrm{~cm}$ at $2070 \mathrm{~m}$, i.e. neoformed micrite seems to precipitate in response to a relationship between burial depth and water depth.

\subsection{Downslope sediment transport: evidence and implications}

Downslope transport of coarse relict shells from the underlying late glacial shelf sediments was probably initiated by bottom organisms that resuspended and injected particles into the overlying water. On the northwestern Africa margin, this process repeated frequently enough, leads to a net downslope transport Einsele et al. 1977). But a high degree of bioturbation in these continental slope sediments must reflect a widespread rich benthonic life. Here, the uneven distribution of gravityinduced deposition, and especially the negligible supply to the northern Balearic slope, can be explained on the basis of the following observations: i) because there is virtually no fluvial input seawater clarity is comparatively high around the Balearic islands and the open slope flux was about $50 \%$ of those measured on the Marseilles and Barcelona open slopes (Heussner et al_ 1998), the same seawater clarity was evidenced in the entire Balearic sea (Pierce and Stanley, 1975) ii) the northern Balearic shelf is a carbonate ramp with depositional surfaces that extend from shore to basin without an abrupt shelf break nor significant canyons and without any sharp changes in facies along the gradient from shallow water to deep water (Fornos et Ahr, 1997). Increases in density resulting from shelf water suspended matter concentrations are normally insignificant in comparison to temperatureinduced density gradients at the shelf break (Pietrafesa 1983). Suspended-sediment concentrations of $10-100 \mathrm{mg} \cdot \mathrm{L}^{-1}$ correspond to an increase of only $0.01-1.10 \mathrm{~kg} \cdot \mathrm{m}^{-3}$ in water density. McCave (1983) favoured shelf water cooling as a reasonable mechanism for increasing off-shelf transport of fine sediments in temperate latitudes. But in the absence of land masses, these interactions at the air, sea, benthic boundary layers are low Huthnance, 1980). Consequently, the low-energy of the northern Balearic margin differs markedly from the Gulf of Lions margin that is primarily controlled by winds event occurrences. Dense waters are formed on the continental shelf during winter by evaporation and cooling, when the dry cold north-westerly winds blow [MilLot. 1990). These dense waters are assumed to spread over the continental shelf bottom and flow down the slope. Similarly, on the Barcelona continental slope, the presence of shelf slope density front favoured advective transport and the connection between the shelf and the deep slope suspended particulate matter (Puig et al. 2000). Wilson and Roberts (1995) proposed the term 'density cascading' to describe the processes by which high-density waters are released from shelf areas and, together with entrained sediments, sink to their compensation level on the adjacent basin. According to these authors, density cascading probably involves 'pelagic draping' of slopes and basins, erosion of the shelf edge, sediment by-passing of slopes and deposition of sands in deep basins. Parts of coarse sediment observed on the Gulf of Lions slope could be attributed to this process with an enhanced winter exportation concomitant with an intensification of the mean flow and current variability Durrieu de Madron and Panouse, 1996). However, the true turbidite deposition seems restricted only to the deeper portions of the basin (Piper and Savoye, 1993; Morris et_al__ 1998)

\subsection{Mass transfer on the north-western slope: a quantitative approach}

Deposition on western Mediterranean slopes results in a broad variety of sedimentary facies. One of the most representative features of the deposits derives from gravity-driven processes. Catastrophic slide deposits were not observed but the features suggest deposition from a dilute underflow of nepheloid layer. Only a bed-by-bed geochemical and sedimentological analysis can recognize the density cascading effect. The quantitative evaluation of sand fraction fluctuations and the presence of biogenic particles derived from the outer shelf and associated with relatively altered organic matter were considered as strong evidences of gravity flow. This is especially obvious for fine-grained sediment in which gravity-induced intervals cannot be directly recognized. Any attempt of quantification in this basin should give a 
Table II. Attempt of a budget of gravity-driven inputs based on the sedimentary column studied in some cores of the Gulf of Lions slope.

\begin{tabular}{lccccc}
\hline Station & $\begin{array}{c}\text { \% gravity-driven } \\
\text { inputs } \\
\text { (sand fraction) }\end{array}$ & $\begin{array}{c}\text { \% excess related to } \\
\text { gravity-driven processes } \\
\text { (based on C/N ratio) }\end{array}$ & $\begin{array}{c}\text { \% gravity-driven } \\
\text { inputs } \\
\text { (fraction }<50 \mu \mathrm{m})\end{array}$ & $\begin{array}{c}\text { \% gravity-driven } \\
\text { inputs } \\
\text { (whole sediment) }\end{array}$ & $\begin{array}{c}\text { gravity-driven input } \\
\text { accumulation rate } \\
\left(\mathrm{g} \cdot \mathrm{cm}^{-2} \cdot \mathrm{yr}^{-1} \text { ) }\right.\end{array}$ \\
\hline BM 5 & 4.5 & 29.4 & 30.3 & 34.8 & 0.025 \\
BM 4 & 11 & 0 & 0 & 11 & 0.009 \\
BL 3 & 0 & 29.4 & 30 & 30 & 0.033 \\
EC 3 & 43 & $\sim 0$ & 23.7 & 43 & 0.054 \\
G 1 & 6 & 28.6 & 29.7 & 0.019 \\
\hline
\end{tabular}

minimal estimation since it is impossible to quantify particles deriving from the upper slope because they are similar to those of the studied section.

A quantitative evaluation of gravity-driven mass has been attempted on the basis of increases in the $\mathrm{C} / \mathrm{N}$ ratio and shallow-water tracers, using ${ }^{210} \mathrm{~Pb}$ datings when possible, i.e. the upper parts of cores BL3 and G1 and the lower parts of cores BM5 and EC3. As a consequence of the original texture of the reworked material, the gravityinduced interval may be caused by mixing with slightly different sand contents: a net excess weight was noted in core EC3 $(43 \%)$, whereas it was smaller in cores G1 (7 \%), BM5 (5.5\%), BM4 (10\%) and nearly imperceptible in cores BL3 and T1.

Our attempt of evaluation of the gravity-induced role is based, in some favourable cases, on an increase of the $\mathrm{C} / \mathrm{N}$ ratio, expressed as an average of $29.4 \%$ for core BL3, 28.6\% for core G1 and as irregular values (20 to $35 \%$ ) for core BM5. The same evaluation applied to the excess sand weight gives $29.4 \%$ for G1 core, $61.5 \%$ for BM5 and $71.4 \%$ for EC3. For better estimating the budget, the sand excess was related to the total sand percentages and the amplitudes in $\mathrm{C} / \mathrm{N}$ change was applied to calculate the gravity-induced part of the non-sandy fraction (table - I t ). The material added to the hemipelagic background of sedimentation was estimated to range from 29.7 to $43 \%$, except for the hybrid example of core BM4 (11\%). These results were derived from four or five core sections out of eight. The statistic basis of this study is obviously inadequate to provide a global budget of gravity transport flow on these slopes and further analyses are needed to test our hypothesis. Significant gravity-induced processes were recorded at a short-term centennial scale. Such episode of rapid deposition was suggested for the changing slope of ${ }^{210} \mathrm{~Pb}$ activity with depth of other cores on the north-western Mediterranean margin (Buscail et al__1997). During long-term accumulation $\left(10^{3}-10^{4} \mathrm{yr}\right)$ mixing of hemipelagic and outer shelf deposits occurs repeatedly which explains the possible discrepancy between ${ }^{14} \mathrm{C}$ and ${ }^{210} \mathrm{~Pb}$ datings.

\section{Acknowledgements}

The authors gratefully acknowledge financial support received from the European Union through the project Euromarge-NB (European Union, MAS2-CT930053) and the Spanish Government through the project (CICYT project AMB92-0251-CO2-01). One of the authors (P. Masqué) received a pre-doctoral grant funded by the Spanish Government. The authors are grateful to Brigitte Deniaux for her help in the improvement of the English version of the script.

\section{REFERENCES}

Abassi, A., 1998. Contribution à l'étude des transferts particulaires sur la marge continentale du golfe du Lion (Méditerranée nordoccidentale), Utilisation de deux traceurs radioactifs : le plomb 210 et le polonium 210. Thèse de Doctorat, université Perpignan.

Anderson, R.F., Rowe, G.T., Kemp, P.F., Trunbore, S., Biscaye, P., et al., 1994. Carbon budget for the mid-slope depocenter of the Middle Atlantic Bight. Deep-Sea Res. Part 2 41, 669-703.

Appleby, P.G., Oldfield, F., 1978. The calculation of Lead-210 dates assuming a constant rate of supply of unsupported $\mathrm{Pb}-210$ to the sediment. Catena 5, 1-8.

Bodur, M.N., Ergin, M., 1994. Geochemical characteristics of the Recent Sea of Marmara. Chem. Geol. 115, 73-101.

Buscail, R., Germain, C., 1997. Present-day organic matter sedimentation on the NW Mediterranean margin: importance of off-shelf export. Limnol. Oceanogr. 42, 217-229.

Buscail, R., Ambatsian, P., Monaco, A., Bernat, M., 1997. ${ }^{210} \mathrm{~Pb}$, manganese and carbon: indicators of focusing processes on the northwestern Mediterranean continental margin. Mar. Geol. 137, 271-286. 
Canals, M., Ballesteros, E., 1997. Production of carbonate particles by phytobenthic communities on the Mallorca-Menorca shelf, northwestern Mediterranean Sea. Deep-Sea Res. II 44, 611-629.

Chamley, H., 1971. Recherches sur la sédimentation marine argileuse en Méditerranée. Sci. Géol., Strasbourg, Mém. 35.

Chrétiennot-Dinet, M.J., 1996. Phytoplankton Report. Euromarge 95 cruise. In: Canals, M., et al. (Eds.), EUROMARGE-NB Final Report. MAST II Program, EU, vol. III-A, Extended contr. 7.

Courp, T., Monaco, A., 1990. Sediment dispersal and accumulation on the continental margin of the Gulf of Lions: sedimentary budget. Cont. Shelf Res. 10, 1063-1087.

Durrieu de Madron, X., Panouse, M., 1996. Transport de matière en suspension sur le plateau continental du Golfe du Lion. Situation estivale et hivernale. C. R. Acad. Sci. Paris 322, 1061-1070.

Einsele, G., Elouard, P., Herm, D., Kögler, F.C., Schwarz, H.U., 1977. Source and biofacies at Late Quaternary sediments in relation to sea-level on the shelf of Mauritania, West Africa. Meteor ForshErgebn. C 26, 1-43.

Font, J., Salat, J., Tintoré, J., 1988. Permanent features of the circulation in the Catalan Sea. Oceanol. Acta 9, 51-57.

Fornos, J.J., Ahr, W.M., 1997. Temperate carbonates on a modern low-energy, isolated ramp: the Balearic platform, Spain. J. Sedim. Res. 67, 364-373.

Giresse, P., Buscail, R., Barusseau, J.P., Charrière, B., 1996. Vertical distribution of biotracers and geotracers from advective and gravity induced inputs in several North Balearic multitube cores. In: Canals, M., Cacho, I., Rodriguez, M.A. (Eds.), EUROMARGE-NB Progress Report, 2nd Annual Report. MAST II Programme, EU, II, contr. No. 45, pp. 153-162.

Got, H., Aloisi, J.C., 1990. The Holocene sedimentation on the Gulf of Lions margin: a quantitative approach. Cont. Shelf Res. 10, 841-855.

Heussner, S., Calafat, A., Palanques, A., 1998. Quantitative and qualitative features of partricles fluxes in the North-Balearic Basin. In: Canals, M., et al. (Eds.), EUROMARGE-NB, Final Report, Synthesis of Scientific Results, II, 3. MAST II Programme, EU, pp. 42-66.

Huthnance, J.M., 1980. Wave, and currents near the continental shelf edge. Progr. Oceanol. 10, 193-226.

McCave, I.N., 1983. Particulate size spectra and origin of nepheloid layers of the Nova Scotia continental rise. J. Geophys. Res. 88, 7647-7666.

Marin, P., Giresse, P., 2001. Particulate manganese and iron in recent sediments of the Gulf of Lions continental margin (north-western Mediterranean Sea): deposition and diagenetic process. Mar. Geol. $172,147-165$.

Masqué, P., 1999. Estudi del comportament del ${ }^{210} \mathrm{~Pb}$ i el ${ }^{210} \mathrm{Po}$ en el mar catalonobalear i el seu us con radiotracadors. Tesi Doctoral, Universitat Autonoma de Barcelona.

Millero, F.J., Morse, J., Chen-Tung, C., 1979. The carbon system in the Western Mediterranean Sea. Sedimentology 20, 29-45.

Milliman, J.D., Müller, J., 1973. Precipitation and lithification of magnesium calcite in the deep-sea sediments on the eastern Mediterranean Sea. Sedimentology 20, 29-45.
Millot, Cl., 1990. The Gulf of Lions' hydrodynamics. Cont. Shelf Res. 10, 885-894.

Moulin, E., Jordens, A., Wollast R., 1985. Influence of the aerobic bacterial respiration of the early dissolution of carbonates in coastal sediments. Proceedings Progress in Belgian Ocean. Res., pp. 196-208.

Morris, S.A., Kenyon, N.H., Limonov, A.F., Alexander, J., 1998. Downstream changes of large-scale bedforms in turbidites around the Valencia channel mouth, north-west Mediterranean: implications for palaeoflow reconstruction. Sedimentology 45, 365-377.

Palanques, A., Puig, P., 1999. Sediment accumulation rates in the southern Barcelona continental margin (NW Mediterranean Sea) derived from ${ }^{210} \mathrm{~Pb}$ and ${ }^{137} \mathrm{Cs}$ chronology. Progr. Oceanol. 44, 313-332.

Pierce, J.W., Stanley, D.J., 1975. Suspended-sediment concentration and mineralogy in the central and western Mediterranean and mineralogic comparison with bottom sediment. Mar. Geol. 19, M15-M25.

Pietrafesa, J.F., 1983. Shelf-break circulation, fronts and physical oceanography: East and West perspectives. In: Stanley, D.J., Moore, G.T. (Eds.), The Shelfbreak: Critical Interface on Continental Margin. S.P.E.M., Tulsa, USA, pp. 233-250.

Piper, D.J.W., Savoye, B., 1993. Processes of Late Quaternary turbidity current flow and deposition on the Var deep-sea fan, north-west Mediterranean Sea. Sedimentology 40, 557-582.

Puig, P., Palanques, A., Guillen, J., Garcia-Ladona, E., 2000. Deep slope currents and suspended particle fluxes in and around the Foix submarine canyon (NW Mediterranean). Deep-Sea-Res. 1, 343-366.

Sanchez-Cabeza, J.A., Masqué, P., Ani-Ragolta, I., 1998. Pb-210 and Po-210 analysis in sediments and soils by microwave acid digestion. J. Radioanal. Nuclear Chem. 227, 19-22.

Sanchez-Cabeza, J.A., Masqué, P., Ani-Ragolta, I., Merino, J., Frignani, M., Alvisi, F., Palanques, A., Puig, P., 1999. Sediment accumulation rates in the southern Barcelona continental margin (NW Mediterranean Sea) derived from ${ }^{210} \mathrm{~Pb}$ and ${ }^{137} \mathrm{Cs}$ chronology. Progr. Oceanol. 44, 313-332.

Stoessel, R.K., 1992. Effects of sulfate reduction on $\mathrm{CaCO}_{3}$ dissolution and precipitation in mixing-zone fluids. J. Sedim. Petrol. 62, 873-880.

Tribble, G.W., 1993. Organic matter oxidation and aragonite diagenesis in a coral reef. J. Sedim. Res. 63, 523-527.

Van Straaten, L.M.J.U., 1966. Solution of aragonite in a core from the southeastern Adriatic Sea. C.I.E.S.M. XXth Congress, Bucarest, Contr. No. 232.

Wegrzynek, D., Jambers, W., Van Grieken, R., Eisma, D., 1997. Individual particle analysis of Western Mediterranean sediment cores, Rhône suspended matter and Sahara aerosols - Investigation of inputs to the sediments. Mar. Chem. 57, 41-53.

Wilson, P.A., Roberts, H.H., 1995. Density cascading: off-shelf sediment transport, evidence, and implication, Bahamas Bank. J. Sedim. Res. A65, 45-46.

Zuo, Z., Eisma, D., Gieles, R., Becks, J., 1997. Accumulation rates and sediment deposition in the northwestern Mediterranean. Deep-Sea Res. II 44, 597-609. 